University of Warwick institutional repository: http://go.warwick.ac.uk/wrap This paper is made available online in accordance with publisher policies. Please scroll down to view the document itself. Please refer to the repository record for this item and our policy information available from the repository home page for further information.

To see the final version of this paper please visit the publisher's website. Access to the published version may require a subscription.

Author(s): Anne Gerritsen

Article Title: The Many Guises of Xiaoluan: The Legacy of a Girl Poet in Late Imperial China

Year of publication: 2005

Link to published version: http://dx.doi.org/10.1353/jowh.2005.0019

Publisher statement: This article was published as Gerritsen, A. (2005). The Many Guises of Xiaoluan: The Legacy of a Girl Poet in Late Imperial China. Journal of Women's History, 17, 2, pp. 38-61. No part of this article may be reproduced, stored in a retrieval system, transmitted, or distributed, in any form, by any means, electronic, mechanical, photographic, or otherwise, without the prior permission of Indiana University Press 


\section{The Many Guises of Xiaoluan: The Legacy of a Girl Poet in Late Imperial China}

\section{Introduction}

In recent years the image of the talented woman writer has greatly enhanced our picture of premodern China. Thanks to the work of scholars like Ellen Widmer, Dorothy Ko, Susan Mann and Kang-i Sun Chang, to mention only a few, reference to a woman in China's imperial past conjures up the image of a strong and sophisticated woman holding a book rather than a picture of the bound foot. ${ }^{1}$ No student of China's late imperial period (roughly between 1500 and 1900) could justifiably claim unfamiliarity with the Chinese woman writer. Annotated compilations of translated writings by women and studies of women's lives have enriched our knowledge of imperial China. ${ }^{2}$ Writing women featured prominently in the cultural centers of China from the sixteenth century onward; collections and anthologies show that women wrote prolifically in a variety of genres. The presence of woman writers in the premodern literary canon does, however, not yet translate into a complete understanding of the Chinese woman writer. The emphasis has been on providing introductions to the writers themselves and close readings of their works. The contexts in which their legacies came into being has received much less attention.

Yet we know from studies of women writers in the Western literary canon the extent to which the woman writer has been largely a male construct. ${ }^{3}$ The ideals of purity, innocence, and passivity that surrounded for example nineteenth-century European woman writers also feature strongly in seventeenth-century China. The ideal 
Chinese woman writer of the late Ming and early Qing dynasties (equivalent to the period from 1500 to 1700) was beautiful, innocent, pure, and above all talented. While we know that in many cases these beautiful and talented women writers received the support and admiration of male writers, the exact nature of the male impact on the construction of a woman's literary legacy has rarely received in-depth attention. ${ }^{4}$ I will argue below, on the basis of a close reading of the reception of the writings of a seventeenth-century teenage poet, Ye Xiaoluan, that we must not underestimate the impact of male authors on the construction of "the Chinese woman writer". We should recognise male attitudes towards women writers not just as supportive of female talent, but also as a shaping force in the construction of her legacy. Scrutinizing the ways in which male writers transmitted the legacy of Ye Xiaoluan will bring into focus the problematic nature of her reception. I will argue that in Xiaoluan's case, our image of her as a writer may well be largely the reflection of an amalgamation of several ideals. The enthusiasm with which modern scholarship has embraced the Chinese woman writer may well have to be tempered with a greater sensitivity towards the social contexts in which their legacies were established.

\section{Ye Xiaoluan (16176-1632)}

This is how an eleven year old girl in Wujiang near Suzhou, one of China's flourishing urban centers in the seventeenth century, expressed herself in 1627:

Holding my mirror in a fresh morning breeze

How can I line my eyebrows now?

Just when I finish the flowers in my hair 
Outside in the willow the oriole sings. ${ }^{5}$

This unusually gifted young girl had only just learned to write in the regulated style in which this poem is composed. ${ }^{6}$ As she grew older, she continued to write, and her poems reflect her maturing talent. Her most famous poems, written months before her death, form a series on a woman's features, ending with one on the full body:

Beauty fills a beholder like a feast, As no adornment of makeup can.

Frowns are all the more enchanting,

Without the ornament of powder and rouge.

As lotus clouds her two cheeks,

Her smile reveals bewitching dimples.

The plum blossom opens into five petals, Its pure beauty is embraced inside. ${ }^{7}$

The girl who wrote these poems was the daughter of Ye Shaoyuan (1589-1649), a promising student from a distinguished family, and Shen Yixiu (1590-1635), the talented daughter of a high government official. ${ }^{8}$ Their marriage had not been their own choice, of course, but they knew their families had been carefully matched, and they shared an interest in book collecting, in poetry, and in Buddhism. ${ }^{9}$ Their children-the couple had five sons and three daughters — were all educated in the home. ${ }^{10}$ The girls "rejected scissors and rulers [the tools for needlework] in favor of brush and ink, and their daily curriculum in the inner quarters was divided between books and musical instruments.”11 Their third daughter was born in 1616, and the name her parents gave her was Xiaoluan. 
Xiaoluan grew up in what was in the early seventeenth century the wealthiest part of China. Both the economy and the population in Jiangnan, the fertile area surrounding the downstream part of the Yangzi River, had rapidly expanded in recent decades, and elite households like Ye Shaoyuan and Shen Yixiu's enjoyed a comfortable and cultured lifestyle. ${ }^{12}$ Even though they were not excessively wealthy, and Ye Shaoyuan had to work hard to provide for his family, there were parties to attend, books to read, paintings and calligraphy to copy, fine teas to sample, and musical instruments to play. ${ }^{13}$ But above all, the Ye girls wrote poetry. They were taught by their father and mother, and exchanged poems with the women within their social circle. The wealthy, sophisticated environment of late Ming Jiangnan produced numerous woman poets, many young and talented like Xiaoluan. ${ }^{14}$ The poet who wrote the lines quoted above was merely a child, and hardly ever ventured beyond the confines of her home. She learned to play the zither (qin), and spent many days on her own in her "Pavilion of Slight Fragrance" (Shuxiangge), while her father began making arrangements for his daughter to marry the son of a suitable acquaintance. Then, suddenly, disaster struck. She fell ill and died less than a month later, just five days before her wedding day, not yet seventeen years of age. Her elder sister, Ye Wanwan, died just months later.

Throughout the following centuries, Xiaoluan's writings caught the attention of many male and female writers. When the learned Wang Duanshu (1621-ca.1706) compiled her anthology of woman poets, “Classic Poetry by Famous Women” (Mingyuan shiwei), between 1639 and 1664, Xiaoluan was included. ${ }^{15}$ She was included in Xu Shumin’s 1690 collection of woman ci poets; Liu Yunfen’s 1673 anthology of women poets even included 36 of Xiaoluan’s poems. Xiaoluan’s poem on a woman’s body parts, 
"Yanti lianzhu”, was particularly popular; it appeared, for example, in a collection entitled Tanji congshu ("Collectanea from the Sandalwood Table”) in the late 1690s.

Qian Qianyi (1582-1664), the leading scholar, official and literary critic of the seventeenth century, included her poems in an annotated anthology of Ming poetry. ${ }^{16}$ Almost 150 years later, the notorious Hangzhou scholar Yuan Mei (1716-1797) too, wrote about Xiaoluan. A prominent scholar and teacher, Yuan Mei had an entourage of women students, and published the poems of his female pupils. ${ }^{17}$ In the nineteenth century, another Hangzhou poet and official, Chen Wenshu (1775-1845) expressed his interest in Xiaoluan in writing. ${ }^{18}$ Even in the early twentieth century her work appeared in several collections; Ye Dehui (1864-1927), the famous conservative politician and book collector, for example, republished her poems. These men were not only famous for their careers as writers and politicians, but also for their recognition and support of female talent. While the participation of women in the literary establishment of pretwentieth-century China, which was almost exclusively a male domain, remained a controversial moral issue, these men openly taught women students or published their writings. Yuan Mei and Chen Wenshu are perhaps the most famous promoters of women's literature in all of Chinese history. ${ }^{19}$ It is largely through the writings and compilations of men like Qian Qianyi, Yuan Mei and Chen Wenshu that women like Xiaoluan are known to us today.

Their interest in Xiaoluan, however, goes beyond mere admiration. Their promotion of Xiaoluan cannot be seen simply as "encouragement from the opposite gender”, as Clara Ho put it in her study of male compilations of texts written by women. ${ }^{20}$ The legacy of Xiaoluan shows the extent to which men constructed and 
shaped the ideal woman writer. The continual process of recreating Xiaoluan's image to fit with constantly changing needs and desires calls to mind the continual recreation of the Greek poet Sappho. The idea that "each commentator constructs a composite element culled from a variety of sources, to which he or she may add only a pinch of fantasy” could apply as well to Sappho as to Xiaoluan. ${ }^{21}$ I will argue below that the "fictions" of Xiaoluan created over the centuries correspond to largely male ideals of what a woman writer ought to be. While these ideals are individual and change over time, they contain certain recurring elements: purity, innocence, fragility, and beauty. Men as well as women participated in the ongoing construction of this ideal, reminiscent of the nineteenth-century European ideal of “death-angels” described by Gilbert and Gubar. ${ }^{22}$ I argue that our appreciation of Ye Xiaoluan should be based on an awareness of the extent of the "fictionalization" in Xiaoluan’s legacy. By focusing on several instances in Xiaoluan's Nachleben, I hope to clarify the ways in which her legacy changed over a period of almost four centuries and the significance of the roles played by her male admirers in the construction of her legacy.

\section{Ye Xiaoluan, Icon of Qing}

In the years that followed the tragic deaths of their daughters, Ye Shaoyuan and his wife embarked upon the project of collecting and publishing their writings, as well as those of other women in their extended circle of friends. The women in the Ye family maintained close ties with other like-minded elite families, and the poems and letters exchanged between these women form the basis of the extended female networks that scholars like Dorothy Ko and Ellen Widmer discuss in their work on women's culture in late-imperial 
China. ${ }^{23}$ Ye Shaoyuan's important role within these networks as collector, editor and publisher, is undisputed. Eternalizing women's writings was a project close to his heart; it became especially important to him when his beloved wife also died, only three years after Xiaoluan’s death.

As soon as the blocks of Xiaoluan’s poems were carved, copies were distributed among women writers in the Jiangnan area. ${ }^{24}$ By 1636, Shaoyuan had gathered the work of eight members of the Ye family, including his wife Shen Yixiu and Xiaoluan, and published this collection as Wumengtangji, or “Collected works from the Daydreamer's Studio”. ${ }^{25}$ Ye Shaoyuan's edition of Xiaoluan's writings was given the title Fanshengxiang, or "Fragrance of Returning Life", to which he added his own commentary. During the early 1640s, several more works were added to the collection, including the records of a number of séances held by Ye Shaoyuan in which the now deceased women of his family appeared and left behind compositions. Xiaoluan's fame as a poet was largely due to the success of Wumengtangji, which included Fanshengxiang. ${ }^{26}$ The popularity of the collection gave her name a good deal of exposure. But what exactly was the nature of Ye Shaoyuan's involvement in the creation of Xiaoluan's reputation?

There can be little doubt that Ye Shaoyuan felt the anguish of a father at his child's death, desperate to understand what happened.

What did I do wrong to cause your death? If it is something I did wrong, then death must also be my fate. ... My friends and family admonish me, telling me to stop grieving with so many sons around me. Why should I feel a persistent attachment to you? Oh, it is too painful.... Of course I ought to love the boys, but 
why should it be different with a girl? ... When you died, I had no desire to live on. $^{27}$

In a postface he composed shortly after Xiaoluan's death, we hear the voice of a mourning father who has lost his beloved child. "All I have left of my daughter in this realm is the fragrance of her trousseau and her vermilion writing brush. ${ }^{, 28}$ He made the decision to publish her writings soon after her death.

My hands still carry her fragrance, moving me deeply. I have now ordered all the woodblocks [to be made] so that I will not forget my initial intentions [of preserving her work]. Not many days and months of grief have passed, spent in exhausting sadness and pain. My awareness is limited, desolately I look out to the springlike trees in the sadness of the evening. She had little more than these few earthly possessions. ${ }^{29}$

These earthly possessions, her poems, and their transmission became the focus of the father's grief.

The extent to which Ye Shaoyuan shaped his daughter's writings will never be known, as we only know Xiaoluan’s writings in Shaoyuan’s edited version that appeared after her death. Awareness of the father's editorial hand does, however, affect our reading of her work. In a piece of prose included in Fanshengxiang, Xiaoluan describes two young girls in the garden. "[They wore] green clothes, and both had their hair tousled by wind and rain. They looked charming and delicate, sitting on the stone seat in front of the courtyard, laughing and chatting and admiring the beauty of the wind and the moon.”30 Xiaoluan expresses her innocent enjoyment of feminine beauty and grace, but we see these girls in Xiaoluan's text through the eyes of a lonely drinker. He secretly 
observes and admires the girls through a slit in the window, as he realises they were spirits of the banana tree in which they suddenly disappear. Xiaoluan's delight in the girls' charms may well also reflect the father's admiration of girls with tousled hair, or indeed of his own daughter's budding beauty. After all, when she returned to her natal family in 1625, after a long stay with her mother's cousin, her father noted in his diary, "She is tall, and her physique is like that of a twelve or thirteen year-old." ${ }^{31}$ These are significant words in a world where girls married often before they were sixteen. At nine, Xiaoluan was, in her father's eyes, on the cusp of womanhood.

While his grief is undoubtedly real, there can be little doubt that Ye Shaoyuan stood to benefit from being known as the father of talented daughters such as Xiaoluan and her sisters. From the late sixteenth century, money spent on a daughter's education was considered a worthwhile investment, and Ye Shaoyuan and his wife would have hoped to arrange good matches for their daughters. But this was an era in which the cult of qing (emotion, feeling) was widespread, and pure feelings were regarded as the ultimate font of all creative inspiration, and the innocent and young Xiaoluan represented much more than just a good match. ${ }^{32}$ When Xiaoluan and her sister Wanwan both died tragically young, they spoke even more to the sensibilities of the time. Like the tragically forsaken concubine Xiaoqing and the literary heroine Du Liniang, whose talent and tragic death made them icons of the cult of qing, Xiaoluan's talent, beauty, and her death combined to make her the ideal personification of qing. ${ }^{33}$

The mourning father must have been aware of the wider appeal of his daughter's story, and was probably largely responsible for the way in which her story became known to later admirers. For the final version of Xiaoluan's poetry collection, to be included in 
Wumengtangji, Ye Shaoyuan asked his wife's relative Shen Zibing to write a preface. Shen Zibing stresses precisely those elements in Xiaoluan's story that fit with the cult of qing.

She was exceptional at birth, and her intelligence was soon established. As she grew up, she had a comely face and a beautiful appearance, her bright beauty unsurpassed. ... When she was just over ten, she knew how to compose rhymeprose; when she was thirteen or fourteen, she could compose literary writings. ... She could recite everything she had read once, she could compose pieces that were resonant, forceful and intriguing. All admired her accomplishment. When she was fifteen she studied qin and chess. She took up the writings and paintings of the old masters and understood them without being taught. Her movement was dignified and light, she never spoke or smiled without forethought. What receives praise in the Book of History and the Book of Documents is also applicable to her. She covered her body and remained in the glorious inner chambers, yet her ambition was as outstanding as a lofty peak. ${ }^{34}$

The emphasis in Shen's description of Xiaoluan is on her beautiful appearance, her unusual and spontaneous talent, and her moral purity. The appeal of the poems themselves is clearly heightened, in Shen's view, by the knowledge that their author was young and beautiful, unusually gifted and morally pure.

The biography of Xiaoluan written by her mother Shen Yixiu shortly after Xiaoluan's death adds an important anecdote. One evening when Xiaoluan was nine, not long after she had returned to her natal family, mother and daughter sat outside. Yixiu uttered a sentence, and Xiaoluan matched it perfectly in parallel rhyme. "At the time we 
rejoiced over her innate ability, which reminded us of 'willow catkins that flutter in the wind', ${ }^{35}$ but alas, it was only to be the evidence for her early death." ${ }^{36}$ The story about Xiaoluan that was distributed by Ye Shaoyuan's capable hands was not the story of an ordinary child. She was extraordinarily talented, she was morally pure, and she was destined to die young. The Xiaoluan he presented to the wider world,and hence the Xiaoluan we know today, corresponded very closely to what was in the early seventeenth century a highly marketable ideal.

\section{Ye Xiaoluan, Immortal}

Ye Shaoyuan clearly had much vested interest in the establishment of his daughter's fame as a poet, and he was highly successful in creating a repution for himself as father of a talented poet. At the same time, however, her reputation spread for another reason. It became known that Xiaoluan had not been a mere mortal. The seventeenth-century Chinese pantheon included a vast number of immortals, who existed in a heavenly realm, which to some extent mirrored the imperial bureaucracy. Immortals fulfilled a range of functions within that heavenly bureaucracy as servants or officials of varying status. They were perceived as superior creatures to human beings, with far greater talents and abilities, but not necessarily devoid of anthropomorphic foibles and follies. The women in the Ye family, and Shaoyuan himself, were deeply religious. Ye Shaoyuan came to believe, and set out to prove, that the deceased women in his family were reincarnated immortals.

He collected and annotated Xiaoluan's poetry in a collection which he entitled “Fragrance of Returning Life.” Throughout Ye Shaoyuan’s commentary to her poetry, 
the emphasis is on signs that indicate, according to Ye Shaoyuan, evidence of his daughter's immortality. As we follow his reading of her poetry, we are struck, as he is, by the melancholy mood that pervades her poetry. "Usually, she enjoyed discussions," he writes in one annotation, "and there was hardly any sadness in her. Yet when she picked up her brush such heart-broken words came out. How could this not be an inauspicious omen?”37 Shaoyuan finds signs of impending doom everywhere. Xiaoluan’s poem, “Wandering by West Lake” reads:

By the embankment the flying catkins rise up, as the sun lowers the mountains turn black.

Painters, oars, the songs of the reeds have all gone, gentle water, the colors so mild. ${ }^{38}$

The lake has turned quiet towards evening; pleasure boats and sightseers have disappeared. As night falls, the fading colors and the falling silence appeal to Xiaoluan more than the bustling sounds of the day time. While one might read this as simple enjoyment of natural beauty, Shaoyuan comments, "Foreshadowed here is that she would transcend this mortal realm., ${ }^{39}$

Even if Ye Shaoyuan's reading of this particular poem is largely colored by his hindsight of her premature death, there are several references in the poems themselves to impending death and hints of the immortal realm. "I fear my years and months are drawing to a close," she writes in one poem, "my tears are like strings of silk." 40 "When will I ride the crane to my immortal home?” ${ }^{41}$ she asks in another poem. For her father, there was little doubt that Xiaoluan knew her stay in this world would be brief. But he still struggled to make sense of it: 
I wonder if in a previous existence she was an immortal? But then why would she suddenly be a beautiful girl in this world? If we say this was because her earthly ties had not been fully severed, then why did she die just when she was about to be married? These things are truly difficult to understand. ${ }^{42}$

The answers to these questions were finally found in a series of séances, carried out between 1636 and 1642 in the Ye home, with the divine assistance of Dharma Master Le'an. ${ }^{43}$ At their first attempt, the medium, in the voice of a young servant, explains that Xiaoluan was at that moment engaged by a higher official. The second time Xiaoluan conveyed the message that she, her sister and her mother, had all become immortals. In a final séance, the full details emerge: a young, flirtatious immortal had had illicit relations with another immortal, and as punishment for her behavior, she had been sent to the mortal realm, where she was to reside in a morally pure family. She was to become engaged in this mortal realm, but because she had shown remorse for her behaviour, she would be allowed to return to the immortal realm just before getting married. Hence her death, or rather, her return to the spiritual world just days before her wedding. ${ }^{44}$

Shen Zibing’s introduction to Fanshengxiang not only creates an authorial persona that is young, beautiful, talented and morally pure, but also stresses Xiaoluan's links with the immortal realm. After describing her "comely face and beautiful appearance” and singing the praises of her modest and proper behavior, he quotes her poetry. But the lines he singles out for praise are chosen for the evidence they provide of her existence as an immortal. Her lines "belong to the roaming immortals," the moonpalace and the residence of immortals are never far away. ${ }^{45}$ In Shen Zibing’s preface, thus, the emphasis is on Xiaoluan the immortal rather than on Xiaoluan the poet. 
Ye Shaoyuan, who so mourned his daughter's death, clearly found ways of coping with the devastating losses that befell his family within the spate of a few years. These séances provided him with the knowledge that the women in his family were now in the place where they belonged. By preserving his daughter’s writings, including those written after her death, he could guarantee the immortality he craved for her. The Xiaoluan that Ye Shaoyuan presents to his reading public, we have to conclude, not only corresponds to the ideals associated with the cult of qing, but also fits into the widespread fascination among the seventeenth-century elite with the spiritual realm, the afterlife and reincarnation.

Xiaoluan's manifestation as an immortal provides an interesting parallel with the late sixteenth-century female visionary Tanyangzi. She too was a young woman who attained immortality after her early death and became known mainly through the writings of male literati. Of course there are differences-Tanyangzi was active as a visionary and a teacher and had several disciples during her lifetime while Xiaoluan's religious experiences were of a more private nature, and had no religious disciples—but the similarities are striking and significant. Both remained untainted by any sexual experiences, both attained immortality, and both were admired by high-profile male scholar-officials. ${ }^{46}$

In 1652, ten years after the last seance took place, the famous poet and literary critic Qian Qianyi (1582-1664) published “Poetry from the dynasties” (Liechao shiji), the collection of poetry he had collected and edited together with his wife, the courtesan Liu Shi (1618?-1664). ${ }^{47}$ It includes 14 poems by Ye Xiaoluan and by some of the other women in her family. The biographical annotation on Xiaoluan is more extensive than 
that of the other women in the Ye family and describes not only her activities during her life time, but also the events surrounding Xiaoluan after her death. ${ }^{48}$ Qian Qianyi, who had written a biography of Dharma Master Le'an, was very interested in spiritual matters. ${ }^{49}$ Qian was particularly taken with the idea of Xiaoluan as an immortal. In Qian's description, Xiaoluan's stay on earth is emphatically temporary. Xiaoluan and her mother and sisters had been born in the Palace of Immortals, and would eventually all be reborn in the Western Paradise. ${ }^{50}$ Qian starts Xiaoluan's entry in Liechao shiji almost immediately with the anecdote about matching her mother's words with a perfect rhyme, which serves not so much to illustrate her talents as to suggest that she would never enjoy a long life. If she was talented, those talents would also be her downfall. Qian acknowledges her talents, "She was a gifted poet who wrote many beautiful lines", ${ }^{51}$ but immediately goes on to pay a great deal more attention to her striking beauty and her natural charms. The real subject of his biography, however, is Xiaoluan the immortal; by the end of the text, her talents have quite disappeared from the reader's memory.

Throughout the seventeenth century, it was Xiaoluan the immortal that continued to inspire her gentleman-readers. Zou Yi (fl 1657) wrote a long biography of Xiaoluan, but it is not the biography of a poet, but the biography of an immortal. ${ }^{52}$ His description creates a very tangible and almost provcative image of Xiaoluan: "She had dark, glossy hair, slender eyebrows and a jade-like neck, red lips and white and clean teeth, a straight nose and seductive dimples;" her "attractive looks" (xiuse) he describes as "edible” (kecan). ${ }^{53}$ Zou's description of the exchange between Ye Shaoyuan and Xiaoluan, now speaking to her father through the voice of the medium, draws heavily on Ye Shaoyuan's own description of these events. ${ }^{54}$ While Ye Shaoyuan's exchange with Xiaoluan was 
set in a context of the grieving father's search for communication with all the deceased members of his family, Zou Yi’s obvious attraction to Xiaoluan allows for a slightly different reading of the passage. The spirit of Xiaoluan communicates that she once was a young female scribe in the moon palace, who had briefly appeared in front of the young son of a nobleman among the flower trellises below her study. This brief encounter left the young man longing to see more of her, and he searched for her everywhere. In answer to the question why the marriage between the reincarnation of the immortal (i.e. Xiaoluan) and the young man (i.e. Xiaoluan's betrothed) could not be completed, the medium replies:

Hanhuang [i.e. the female scribe] happened to flirt with this student, allowing herself to laugh, unaware that her heart had been touched. As soon as the reality became clear to her, she deeply regretted this. She most definitely did not wish to be punished among humans, and be tainted by an impure affair. The upper realm, however, insisted on punishing this one smile, which is why she came here. But because she had such regrets, she did not have to marry him. ${ }^{55}$

This is clearly tittilating; she combines purity and innocence with the unrestrained instinct that responds helplessly to the presence of a male. Her regret over her actions and her desire to preserve her purity only serve to enhance the appeal. One wonders if the father, when he first recorded it, was entirely unaware of the sexual dimensions of this exchange; the context of Zou Yi’s tangible description of Xiaoluan’s beauty suggests that Zou most certainly was aware of it.

Zou Yi was not alone; as Judith Zeitlin has pointed out, the scholar-poet You Tong (1618-1704) was similarly infatuated with Xiaoluan. ${ }^{56}$ You Tong was supportive 
of female talent, contributed prefaces to anthologies of women's poetry, and was clearly impressed with Xiaoluan’s abilities as a poet. But it is the "transcendent beauty” (xianzi) of her collection he praises, and it is as spirit of the planchette that she appears in You Tong’s romantic comedy, “Celestial Court Music” (Juntian yue). ${ }^{57}$ His poems resonate heavily with Xiaoluan's own premonitions.

Broken hearts and fragrant grasses ${ }^{58}$ fill even the remotest corners of the earth, The desolate western wind blows in every path and village.

On my pillow I dream of a soul as light as a leaf,

When will I ride the crane to my immortal home? ${ }^{59}$

In the first two lines, You Tong represents his sentiments-heartache, steadfastness, desolation — as universal experiences. The third and fourth, however, are his personal ode to Xiaoluan: the "leaf" (ye) in his dream is also the Ye of her last name; the last line is taken verbatim from her poem "Writing down my feelings." 60 But it is Xiaoluan the immortal being he evokes, not Xiaoluan the poet, the reference not so much to her literary skill as to her presentiment of her impending death.

In many ways Yuan Mei’s late eighteenth-century representation of Xiaoluan is the culmination of Xiaoluan's posthumous career as an immortal being. Yuan Mei’s very short piece on Xiaoluan starts with an anecdote. A young man, dozing over his books, dreams of an immortal, a clerk in the Moon Palace, who tells him she has a predestined bond with him. He awakes, startled, unable to identify the girl. Years later — the young man now holds office in Guangdong — he finds a small portrait of Ye Xiaoluan in a market. Only then does he realise who the immortal in his dream had been. Yuan Mei adds, by way of explanation: 
Xiaoluan was from Yue [Guangdong Province]. When she came of age, she became a nun. She was initiated by the Great Master of Yuelang. Those who are initiated in the Way of the Buddha are only allowed to repent their since after they have themselves first stated the sins committed during their lifetimes. The master asked her: 'Have you committed the crime of wantonness?' She answered: 'I have sung the love song 'Seeking a female phoenix, ${ }^{61}$ and I have opened a scroll and looked ashamedly at 'Coming out of the bath'. ${ }^{62}$

A few more questions and answers follow, in which Xiaoluan confesses to having cursed the wind that was harming flowers, and having accidentally damaged the wings of a butterfly. Striking about this passage is not just the fact that Yuan Mei gets her biographical details wrong, but also the rather voyeuristic insight into Xiaoluan's 'crimes of wantonness.' Clearly Xiaoluan's brief span on earth, her life in Shuxiang Pavilion in Wujiang County (Jiangsu Province) plays no part in Yuan Mei’s imagination of her. Instead, the emphasis is on her transition to another world. In the same way that Zou Yi dwelt on her flirtatious behavior, Yuan Mei relishes the hints of Xiaoluan's budding sexuality, only enhanced by her innocence and shame.

When the deeply religious Ye Shaoyuan found evidence that his daughters and his wife had found a home among immortals, this must have been a deeply consoling thought. But Xiaoluan the Immortal, as her father represents her, becomes attractive to those who transmit her name for more than just religious reasons. Even if we ignore the possibility that the father was conscious of his daughter as a sexual being, it is clear that the transmission of Xiaoluan's name after Ye Shaoyuan’s lifetime was often paired with a delight in Xiaoluan's sexuality. Imagining Xiaoluan as an immortal allows these men 
to play with the tantalising combination of her sexual awakening and her untainted moral purity. We know about Xiaoluan because she appears in the writings of literary giants like Ye Shaoyuan, Qian Qianyi, You Tong and Yuan Mei. But it is important to recognise that her poetic skills, if present at all, do not play a significant part in the seventeenth- and eighteenth-century male transmission of her name.

\section{Xiaoluan and the Nineteenth-Century Interest in Late Ming Sensibilities}

During the late eighteenth and early nineteenth centuries, Xiaoluan continued to attract the interest of male literati. Prominent scholar-officials wrote poems about her, and several lesser-known literati dedicated years of their lives to the preservation and transmission of her legacy. Among these men, too, I would argue, her poetry is not central to her reception. Instead, I suggest, we should see the renewed interest in Xiaoluan as part of two wider, and well-known trends: the nineteenth-century revival of interest in Ming-style politics and what has been called the nineteenth-century "nostalgia” for the late Ming. James Polachek, in his seminal The Inner Opium War, has argued for an early nineteenth-century "rehabilitation of Ming political ideals." ${ }^{63} \mathrm{He}$ shows convincingly that early nineteenth-century literati regrouped themselves in the kind of political factions that had characterized late Ming politics. Like their Ming counterparts, these nineteenth-century groups of literati activists met under the aegis of poetry clubs. In such circles, writing poetry together was a political act, as it had been in the Ming.

While high-level scholar-officials forged political connections while discussing poetry, others used poetry to express what Ellen Widmer and Kang-i Sun Chang have 
referred as "Ming nostalgia." At the forefront of this movement was the poet Chen Wenshu, who wrote extensively about late Ming literary figures, and about Hangzhou, the famous site of Ming loyalism. During the 1820s, Chen Wenshu spent time in Hangzhou, where he had located the graves of three women, two of them directly associated with the late Ming. Chen restored their graves, and built a pavilion for their commemoration. ${ }^{64}$ Chen and his friends and pupils then collected and published all materials written by and about these three women. In the more relaxed political atmosphere of the Jiaqing (1796-1820) and Daoguang (1821-1850) reigns, Ming loyalism was no longer politically dangerous, and republishing the writings of Ming loyalists a popular activity in these circles. As Widmer and others have suggested, Chen and his circle's interest in the Ming dynasty was romantic rather than driven by political motivations. ${ }^{65}$

Ye Xiaoluan's story was well known among representatives of both overlapping circles. Chen Wenshu and many of his friends and pupils, involved in the Hangzhou grave restoration project also wrote about Xiaoluan, as did men like Wang Chang (17251806), Yang Fangcan (1754-1816), Shi Yunyu (1756-1837), and Wu Songliang (17661834). Wang Chang and Wu Songliang were important members of Polachek's networks of literati-activists, while Chen Wenshu and Yang Fangcan were both proteges of famous poetry club members. There are other connections between these men, too; they were all, directly or indirectly, linked to Yuan Mei, and they were all interested in writing women. Wang Chang was a contemporary of Yuan Mei, Wang Chang’s pupil Yang Fangcan a friend of Yuan Mei, Yang Fangcan’s friend Chen Wenshu an ardent admirer of Yuan Mei. Wang Chang was acquainted with woman poets like Xu Yingyu (1720-50) and Sun 
Yunhe (late eighteenth-early nineteenth centuries). Yang Fangcan’s daughter was a poet, his closest friend married to Yuan Mei’s foremost female pupil Xi Peilan (1760-1820?). Wu Songliang taught the woman poet and painter Luo Qilan (late eighteenth century), Chen Wenshu was a noted patron of woman painters and artists. These men all moved in circles that were generally supportive of the writing women, and all five, among many other nineteenth-century gentlemen, wrote about Xiaoluan. Yet, I would argue, their writings about Xiaoluan do not reveal an explicit recognition of her literary talents. These authors, too, "fictionalize" an image of Xiaoluan that fits their own outlook. Wang Chang, for example, had visited the site of Ye Xiaoluan's pavilion, and wrote a piece entitled "Passing Fen Lake, Visiting the Remaining Foundations of the Hall of Meridian Dreams and Shuxiang Pavilion.” After describing the location, he writes:

Before these talented ladies [lit. 'painted eyebrows'] could complete their writings, three lives came to an end. I have heard that this beautiful maiden was about to tie the knot when she transcended, disappearing among the clouds. ${ }^{66}$ Left behind, after Xiaoluan has travelled to her moon palace, are only short poems and fragments. Clearly, Wang Chang is more informed than Yuan Mei about Xiaoluan's life; he imagines her as a writer in her pavilion. But the themes of Wang Chang's brief piece-Xiaoluan's ephemeral beauty, her early death, her transcendence to the realm of immortals - are by now very familiar; her writing itself is not among them. For Wang, Xiaoluan symbolizes absence and loss, even in the brief fragments of poems she has left behind. 
Wu Songliang’s poem about Xiaoluan introduces a new element: her inkstone decorated with a carving in the shape of an eyebrow. His poem, entitled "To Ye Xiaoluan's eyebrow-shaped inkstone,' reads:

By a small pond fine rain moistens the pear blossom, In my mind's eye I see the crooked reflection of a slender moth.

It leaves behind an arch in the shape of the new moon, I do not know where the pair of inkstones found their homes. ${ }^{67}$ Here Xiaoluan is evoked through an object that once belonged to Xiaoluan. If the inkstone was once in Xiaoluan's possession, it is lost now; if she used the inkstone to write poems, these poems themselves, again, are absent.

These two texts, Wang Chang's description of his visit to Xiaoluan's pavilion and Wu Songliang's musings about Xiaoluan's inkstone, are only brief. They contain no indications that these two officials actually read her poems; they merely suggest familiarity with the enduring elements of her story: her beauty, her youth, and her early death. They add, however, two important ingredients to the nineteenth-century reception of Xiaoluan: the restoration of her pavilion and the transmission of her inkstone.

In 1849, a low-ranking official by the name of Wang Shoumai traveled to a new posting. In a market enroute, he came across a small inkstone. When he found two short poems engraved on the back of the inkstone, he became convinced it had once belonged to Xiaoluan. Looking through her collected poems, he discovered that these two poems were not included. Wang then set about collecting everything he could find about her, including a number of poems that had been written by later admirers of Xiaoluan. In 1854, when Wang’s collection was about to be published under the title "Collected 
writings on the fate of an inkstone," Wang was contacted by another admirer of Xiaoluan: a descendant of the same Ye family with a strong interest in family history. This man, named Ye Naiqin, had come across Xiaoluan in the family records in the 1830s, and had been deeply disturbed by the fact that the family burial site had been dug over and put to agricultural use. His search through the archival records had then revealed that Xiaoluan and her siblings had not been buried at the family burial site: they had only been given temporary graves, and the completion of the burial procedures had been disrupted by the events surrounding the fall of the Ming and the conquest of the Qing in the 1640s. But he had been able to locate the temporary burial mounds of Xiaoluan and her sisters, and now tried to persuade Wang Shoumai to visit the location with him. Eventually the two men met, and traveled first by boat to a nearby temple, and then on foot, through rampant weeds, to the temporary graves of the Ye girls. They burned some incense and made an offering on what they speculated to be Xiaoluan's mound, paying their respects to this teenage poet, who had died more than two hundred years earlier. In the years that followed this visit to the grave the two men were in frequent contact. They exchanged letters, and wrote prefaces and epilogues to each other's writings.

For Wang Shoumai, the ink stone symbolized a link between Xiaoluan and himself. Hence the title of his poetry collection: "Collected writings on the fate of an inkstone.” The term I have translated as "fate” (yuan) has resonances of a predestined link, a connection that transgresses human boundaries of time and space, which explains why the ink stone continues to be significant. But yuan is also a love relationship. Two people brought together by fate, a love that was “meant-to-be”. When Wang Shoumai 
stumbles upon this ink stone among the bric-a-brac of a market enroute to a new post, his life is changed for ever. He takes on the responsibility of that fated relationship, which drives him to publish a collection of all the poems about Xiaoluan, the "Collected writings on the fate of an inkstone”. As he says in his own preface to the collection, "If I did not pass on the story of this ink stone, and make it flourish, I ought not to have taken the responsibility of this fated relationship.”68

The ink stone also connects Wang Shoumai to Xiaoluan as her lover. A long poem written by Wang Shoumai suggests perhaps how little their separation by two hundred years hindered the development of his feelings for her. He begins by describing Xiaoluan.

She is graceful and charming, this third branch of a pearl-bearing tree.

Intelligent like pure snow, her appearance like the moon reflected in water.

The pearl and the moon both are common descriptors for feminine beauty, and water is associated with the feminine, the yin in yin-yang theory. Water is soft, yielding, pliant, and hence also used to denote the feminine in sexual terms, giving his description of her distinct sexual overtones. The next lines continue like this:

Like mandarin ducks on white earth, by day they embroider,

like parrots by a green window, by night they study poetry. The plural, referring to Xiaoluan and her sisters, gives the girls a shared intimacy, as their embroider and write poetry. Their shared activity perhaps excludes the observer, but also enhances his position as voyeur, looking at them through the window. By day they conjure up the image of the mandarin ducks, a common metaphor for conjugal bliss as well as the sibling love that connected the sisters, an image made famous in Yuanyang 
meng, "Dream of Mandarin Ducks”, written by the sole surviving Ye sister. ${ }^{69}$ But by night they become "parrots." The parrot, often just a reference to a young girl, can also be a metaphor for a young girl in a brothel, which takes on further significance considering that the poetry women wrote was often condemned precisely because writing poetry implied promiscuity in that a woman's most intimate thoughts would circulate among strange men. For Wang Shoumai, through whose eyes we see Xiaoluan here, the sexual overtones are clearly part of the attraction.

Further on in the poem, he describes Xiaoluan in her pavilion:

Desolate and lonely in Shuxiang Pavilion, an empty curtain, who greets the slender moon?

The ambiguity of the classical Chinese leaves open whether it is her feelings that are desolate and lonely, or his. Equally, the slender moon could refer to her in her loneliness, but also to her in her residence among immortals, in which case it creates the suggestion that it is him she is waiting for. The next lines elaborate on this:

This curved new moon, shaped like an eyebrow, the inkstone linked you to me, as I traveled to my new post. ${ }^{70}$

The new moon refers, of course, to Xiaoluan herself, linked through the symbol of the eyebrow on the inkstone to Wang Shoumai.

Wang Shoumai's nineteenth-century imagination of Xiaoluan combines, thus, the same ingredients: her beauty, her sheltered existence, and hence her purity, as well as her emotional as well as sexual availability. If we characterize certain cultured circles of the early nineteenth century by their revival of interest in Ming-style poetry clubs and the poets of the late Ming themselves, then sooner or later the members of these circles 
would come across Ye Xiaoluan. But the writings of men like Wang Chang, Wu Songliang, and Wang Shoumai suggest that it was not her poetry that fired their imagination. Once again, the attributes she gained in the transmission of her story are more attractive than her authorship itself.

\section{Xiaoluan as illustrious member of the Ye family}

While Wang Shoumai created a very personal image of his Xiaoluan, Ye Naiqin was interested in more mundane things. His interest in Xiaoluan was focused on Xiaoluan's grave itself: its location, the location of the pavilion where she had worked, and any other concrete information he could put his hands on. He kept a diary which starts in November 1855 and ends in July $1858 .^{71}$ Each visit to her grave is described, with an appendix where all the costs incurred are recorded, including labor costs for clearing the weeds, their overnight expenses, and the fees paid to the monks for their religious services. ${ }^{72}$ Fascinating as all this detail is, it actually tells us very little. Ye Naiqin is clearly interested in family history, and expends a great deal of effort and resources to establish an accurate record. But in his case, the means are almost more important than the end. Eighteenth- and nineteenth-century scholars in China were obsessed with philology, searching for origins, and with setting the records straight through presenting a great deal of evidential detail. ${ }^{73}$ Ye Naiqin seems to have latched on to Xiaoluan as a project more to show off his grasp of the methodology than to prove a particular point about Xiaoluan herself.

In 1896 a new edition of Fanshengxiang appeared, and for the first time her work

was printed as an individual collection. ${ }^{74}$ Her poetry also appeared in twentieth-century collectanea: it was included in the 1914 Xiangyan congshu (Collectanea of the fragrant 
and beautiful) and in 1917 in Yuxuanshi xiaopin. In the same year, an illustrious descendent of the Ye family, Ye Dehui, published a collection entitled "Posthumous Record of the Pavilion of Slight Fragrance” (Shuxiangge yilu). This text contains Ye Dehui's chronological account of Xiaoluan's seventeen years of life, the full text of all biographical entries for Xiaoluan written over the centuries, all of the material related to Ye Naiqin and Wang Shoumai's visits to her grave, and many later poems dedicated to Xiaoluan.

As opposed to Ye Naiqin and Wang Shoumai, who remain complete unknowns in Chinese history, Ye Dehui was a prominent political actor. He was a complicated mix of conservatism and progressiveness (he ranted against the tentative efforts at reform made by the Qing dynasty in its waning years, and insisted on the importance of Confucian learning, and yet he was the first Chinese to publish openly a collection of medical works on sex, ${ }^{75}$ and he worked for a time as a businessman, contrary to all Confucian principles). But it was as bibliographer and editor that he achieved nationwide fame: his edition of the History of the Mongols is still the best extant edition today, and his annotated catalogue of the thousands of fine books in his personal library remains an important bibliographic source. As he said himself: "For those who seek immortality, nothing is better than re-publishing old books.,76

A small but significant portion of his work deals with his own family history. Between 1904 and 1911 he published 12 works written through the centuries by members of the Ye family, who traced their descent back to a twelfth-century ancestor. He compiled a new edition of the genealogical record of the Ye family, which contained all writings by the members of the Ye family. His motivation, as he said himself, was 
"preserving the family's learning and promoting the virtue of the generations." person he promoted most enthusiastically was the third daughter of a late Ming ancestor, none other than Ye Xiaoluan. In his introduction to the collection of writings associated with Xiaoluan, he refers to her as his "great-aunt of nine generations ago," whose “extraordinary skill at poetry and broad literary learning" must be "passed on and made known.,78

The closest Ye Dehui comes in talking about her directly is in his postface to the collection. He quotes Xiaoluan's words “spoken” in an appearance as a spirit to her father.

The patterns of the world are not constant, principles vanish like the sparks of a firestone or froth on water. I would rather be stirred by such things! Once Fanshengxiang has been printed, it will just be like a bag of lime that leaves traces behind. If it leaves its traces everywhere, won't that be tiresome? ${ }^{79}$ Xiaoluan refers here to the impermanence of all things in this world, an indication of her Buddhist piety. The illusion of permanence provided by the printing of her poetry is to her nothing more than the dust left behind by a bag of lime, annoying perhaps, but easily swept away. She, in her immortal existence, did not need to worry about leaving her traces in this world, he suggests in the next line, but, he writes, we mortals do worry about the mark we make in this world, and we worry about the accuracy of the texts we pass on. The purpose of this compilation, he concludes, is to glorify the members of this family. ${ }^{80}$ So while Xiaoluan had an immortal's prerogative of not having to worry about achieving immortality, Ye Dehui did worry about it. And as he had chosen to "re-publish 
old books” as his way to leave his mark behind, he worried about the accuracy of the texts he transmitted. Ye Xiaoluan thus performs two roles for Ye Dehui: she allows him to glorify his own family, and she helps him achieve the immortality he craved.

\footnotetext{
${ }^{1}$ For examples of these scholars’ works, see Ellen Widmer, “The Epistolary World of Female Talent in Seventeenth-Century China” Late Imperial China 10, no. 2 (1989): 1-43; Dorothy Ko, Teachers of the Inner Chambers: Women and Culture in Seventeenth-Century China (Stanford: Stanford University Press, 1994); Susan Mann, Precious Records: Women in China's Long Eighteenth Century (Stanford: Stanford University Press, 1997); Kang-i Sun Chang, “Ming and Qing Anthologies of Women’s Poetry and Their Selection Strategies,” in Writing Women in Late Imperial China, eds. Ellen Widmer and Kang-i Sun Chang (Stanford: Stanford University Press, 1997).

${ }^{2}$ Kang-i Sun Chang and Haun Saussy, eds. Women Writers of Traditional China: An Annotated Anthology of Poetry and Criticism (Stanford: Stanford University Press, 1997).

${ }^{3}$ Sandra Gilbert and Susan Gubar, The Madwoman in the Attic: The Woman Writer and the NineteenthCentury Literary Imagination (Yale Nota Bene Books, 2000), 16-20.

${ }^{4}$ An important exception is Wilt Idema, "Male Fantasies and Female Realities: Chu Shu-chen and Chang Yü-niang and their Biographers,” in Chinese Women in the Imperial Past: New Perspectives, ed. Harriet T. Zurndorfer (Leiden: Brill, 1999), 19-52.

${ }^{5}$ Ye Xiaoluan, “Getting dressed on a spring morning,” Fanshengxiang, in Ye Shaoyuan, ed., Wumengtangji (1636; reprint, Beijing: Zhonghua shuju, 1998), 311. The translation is mine, based on W.L. Idema, De Onthoofde Feministe (Amsterdam and Antwerpen: Uitgeverij Atlas, 1999), 336. Throughout, the translations are mine, unless indicated otherwise.

${ }^{6}$ The poem is a jueju with five characters per line. For more information on poetic styles and conventions, see Wilt Idema and Lloyd Haft, Guide to Chinese Literature (Ann Arbor: University of Michigan, 1997). For biographical details on Xiaoluan, see Ye Dehui, “Account of her life” in Shuxiangge yilu, ed. Ye Dehui (1917; reprint, Shanghai: Congshu jicheng xubian, 1998), 91-95.
} 
${ }^{7}$ Ye Xiaoluan, “The full body” Fanshengxiang, 351, translated by Ko, Teachers of the Inner Chambers, 168.

${ }^{8}$ On Shen Yixiu (1590-1636), see Ko, Teachers of the Inner Chambers, 187-218.

${ }^{9}$ Ko, Teachers of the Inner Chambers, 187.

${ }^{10}$ Kang-i Sun Chang and Haun Saussy, Women Writers of Traditional China: An Anthology of Poetry and Criticism (Stanford: Stanford University Press, 1999), 266.

${ }^{11}$ Shi Yunyu (1756-1837), “Biography of Ye Xiaoluan” in Ye, Shuxiangge yilu, 2.10b.

${ }^{12}$ For an introduction to the social and economic environment of the late Ming, see for example Evelyn Rawski, “Economic and Social Foundations of Late Imperial Culture,” in Popular Culture in Late Imperial China, ed. David Johnson et al. (Berkeley: University of California Press, 1985), 3-33, or Timothy Brook, The Confusions of Pleasure (Stanford: Stanford University Press, 1998).

${ }^{13}$ On the economic troubles the Ye family faced, see Joseph Poon.

${ }^{14}$ Only a fraction of these writings have been preserved; far more were destroyed by women writers themselves, preferring not to circulate their work among strangers as having a woman's writings seen by male eyes was tantamount to being promiscuous. Clara Wing-chung Ho, "Encouragement from the Opposite Gender: Male Scholars’ Interests in Women’s Publications in Ch’ing China—A Bibliographical Study,” in Chinese Women in the Imperial Past: New Perspectives, ed. Harriet Zurndorfer (Leiden: Brill, 1999), 314 or Idema, De Onthoofde Feministe, 8. For a comprehensive listing of writings by women, see Hu Wenkai, Lidai funü zhuzuokao (Shanghai: Guji chubanshe, 1985). In Chang and Saussy, Women Writers of Traditional China, extant poems by women and criticism by and about woman writers have been translated.

${ }^{15}$ On Wang Duanshu’s anthology of women poets, see Chang, “Ming and Qing Anthologies,” 157-9. On Wang Duan, see Widmer, "Ming Loyalism.”

${ }^{16}$ Qian Qianyi worked on this anthology together with his wife, the famous courtesan Liu Rushi (16181664). On Qian Qianyi, see for example Lynn Struve, “Huang Zongxi in Context: A Reappraisal of his Major Writings,” Journal of Asian Studies 47, No. 3 (1988): 474-502. On Liu Rushi, see Kang-i Sun Chang, The Late Ming Poet Ch'en Tzu-lung: Crises of Love and Loyalism (New Haven: Yale University 
Press, 1991) and Ko, Teachers of the Inner Chambers. On the anthology, see Chang, "Ming and Qing Anthologies”, 153-156.

${ }^{17}$ It was entitled "Collected Poems from the Entourage of Women Poets at Sui Garden”, and printed in 1796. Susan Mann, “ ‘Fuxue’ (Women’s Learning) by Zhang Xuecheng (1738-1801): China’s First History of Women’s Culture,” Late Imperial China 13, No. 1 (1992): 40-1.

${ }^{18}$ On Chen, see Arthur W. Hummel, ed., Eminent Chinese of the Ch'ing Period (Washington, D.C.: U.S. Government Printing Office, 1943-44), 103-4; Ellen Widmer, “Xiaoqing’s Literary Legacy and the Place of the Woman Writer in Late Imperial China,” Late Imperial China 13, no. 1 (1992): 139-142; Ellen Widmer, "Ming Loyalism and the Woman's Voice in Fiction after Hong lou meng," in Writing Women in Late Imperial China, eds. Ellen Widmer and Kang-i Sun Chang (Stanford: Stanford University Press, 1997), 366-396.

${ }^{19}$ For a listing of Qing intellectuals supportive of women’s writings, see Ho, “Encouragement from the Opposite Gender,” 310 (note 9).

${ }^{20}$ Ho, “Encouragement from the Opposite Gender,” 308ff.

${ }^{21}$ Fictions of Sappho, 9. There is a rich literature on the (re-)creation of Sappho’s legacy. See, for example, Yopie Prins, Victorian Sappho (Princeton: Princeton University Press, 1999); Re-Reading Sappho: Reception and Transmission, ed. Ellen Greene (Berkeley, Los Angeles, London: University of California Press, 1996).

${ }^{22}$ Gilbert and Gubar, Madwoman, 24-25.

${ }^{23}$ Ko, Teachers of the Inner Chambers; Widmer, “The Epistolary World;” Mann, Precious Records.

${ }^{24}$ Ko, Teachers of the Inner Chambers, 212.

${ }^{25}$ I follow here the translation of this title used in Chang and Saussy, Women Writers of Traditional China, 267.

${ }^{26}$ For exact details on the various editions, see Ye, Wumengtangji, 12-20.

${ }^{27}$ Ye, Wumengtangji, 372.

${ }^{28}$ Ye, Wumengtangji, 356.

${ }^{29}$ Ibid. 
${ }^{30}$ Ye Xiaoluan, “A night by the banana tree window,” Fanshengxiang, in Ye, Wumengtangji, 352-3.

${ }^{31}$ Ye Shaoyuan, Ye Tianliao zizhuan nianpu, in Ye, Wumengtangji, 837.

${ }^{32}$ Huang

${ }^{33}$ Ko, Teachers of the Inner Chambers, 68-112.

${ }^{34}$ Shen Zibing, "Preface” in Ye, Wumengtangji, 299-300.

${ }^{35}$ The allusion to willow catkins lifted by the wind refers to a famous line written by Xie Daoyun (fl. 399).

"Catkin verses" later became a phrase referring to the fragility of the lives and works of women poets.

Chang and Saussy, Women Writers of Traditional China, 7.

${ }^{36}$ Shen Yixiu, “Biography of my youngest daughter Qiongzhang,” in Ye, Wumengtangji, 201.

${ }^{37}$ Ye, Wumengtangji, 310.

${ }^{38}$ Ye Xiaoluan, “Wandering by West Lake”, Fanshengxiang, in Ye, Wumengtangji, 311.

${ }^{39}$ Ye, Wumengtangji, 311.

${ }^{40}$ Ye, Fanshengxiang, in Ye, Wumengtangji, 302.

${ }^{41}$ Ye, Fanshengxiang, in Ye, Wumengtangji, 330.

${ }^{42}$ Ye, Wumengtangji, 340.

${ }^{43}$ For a biography of Le'an, see Qian. For a close analysis of Ye Shaoyuan’s account of these seances, see Zeitlin, “Spirit Writing”, 109.

${ }^{44}$ Ye, "Yaowen” and “Xuyaowen”, Wumengtangji 511-526.

${ }^{45}$ Shen Zibing, "Preface” in Ye, Wumengtangji, 300.

${ }^{46}$ Ann Waltner, “T’an-yang-tzu and Wang Shih-chen: Visionary and Bureaucrat in the Late Ming,” Late

Imperial China 8, no. 1 (1987): 105-133.

${ }^{47}$ On their cooperation, see Chang, “Ming and Qing Anthologies,” 153-5.

${ }^{48}$ Qian Qianyi’s biographical annotation on Ye Xiaoluan is reproduced in Ye, Wumengtangji, 1081-2.

${ }^{49}$ Qian Qianyi, Liechao shiji, in Ye, Wumengtangji, 1082. Qian Qianyi, “Tiantai Le fashi lingyi ji,” in Qian Qianyi, Muzhai chuxue ji.

${ }^{50}$ Qian Qianyi, Liechao shiji, in Ye, Wumengtangji, 1081-1082

${ }^{51}$ Qian Qianyi, Liechao shiji, in Ye, Wumengtangji, 1082. 
${ }^{52}$ Zou Yi, “Biography of a female immortal” (Nüxianzhuan), in Ye, Wumengtangji, 1088-1091.

${ }^{53}$ Zou, "Biography of a female immortal," 1088.

${ }^{54}$ Ye Shaoyuan, Xuyaowen, in Ye, Wumengtangji, 518-520, especially 520.

${ }^{55}$ Zou, "Biography of a female immortal,” 1088.

${ }^{56}$ WWTC 769. For a biography of You Tong, see Hummel, Eminent Chinese, 935-36; Zeitlin, "Spirit Writing.”

${ }^{57}$ The reference to Xiaoluan's collection occurs in You Tong’s preface to Linxia cixuan, cf. Hu, Funü zhuzuo kao, 896. See also WWTC, 769. For a discussion of You Tong's pla7y, see Zeitlin, "Spirit Writing.”

58 “Fragrant grasses” refers to steadfast gentlement. It is an allusion from the Lisao, where Qu Yuan expresses his regret that yesterday’s fragrant grasses (i.e. the upright gentlemen) today are nothing more than useless weeds (insincere deceivers).

${ }^{59}$ You Tong’s poem is included in Ye Dehui’s collection. Ye, SXGYL, 15a.

${ }^{60}$ Ye, Fanshengxiang, in Ye, Wumengtangji, 330.

${ }^{61}$ The title refers to a poem by Sima Xiangru (179-117 BCE), and has become common parlance for the search for a partner.

${ }^{62}$ Yuan Mei, Suiyuan shihua, in Yuan Mei quanji vol. 3. Edited by Wang Yingzhi $/ \uparrow \uparrow \perp \bullet \odot$. Nanjing: Jiangsu guji chubanshe, 1993, 177-178.

${ }^{63}$ Polachek, Inner Opium War, 99.

64 "Record of the three female scholars of West Lake”, by the lady scholar of Qiantang, Guan Jun. Lanyinji, shang, 25a-27b. Guan Jun was one of the concubines of Chen Wenshu. On Guan Jun and her writings on Xiaoqing, see Widmer, “Xiaoqing’s Literary Legacy.”

65 Widmer 1997: 367; Widmer 1992: 40; Chang 1997: 168. See also Gerritsen, “The fashion for the late Ming" forthcoming.

${ }^{66}$ SXGYL 128.

${ }^{67}$ Ye, SXGYL, 20a.

${ }^{68}$ Ye, Shuxiangge yilu, 4.48b-49a.

${ }^{69}$ Ye Xiaowan, Yuanyang meng, in Ye, Wumengtangji, 387-401.

${ }^{70}$ Wang Shoumai, “Untitled” in Ye, Shuxiangge yilu, 4.1b-2a. 
${ }^{71}$ Ye, Shuxiangge yilu, 3.12b-26a.

${ }^{72}$ Ye, Shuxiangge yilu, 3.26b-28b.

${ }^{73}$ Elman.

${ }^{74}$ The Qiumeng'an edition was published in 1896 in Yangcheng (Guangzhou) and has a postface by Ye Yanlan.

${ }^{75}$ Howard L. Boorman, ed. Biographical dictionary of Republican China (New York: Columbia University Press, 1967-79), 35-37.

${ }^{76}$ Zhang Chengzong and Du Maizhi, Ye Dehui pingzhuan [Critical biography of Ye Dehui] (Changsha:

Yuelu shushe, 1985), 109

${ }^{77}$ Zhang and Du, Ye Dehui, 109.

${ }^{78}$ Ye Dehui, “Postface” in Ye, Shuxiangge yilu., 149.

${ }^{79}$ Ye Shaoyuan, “Xu Yaowen” in Ye, Wumengtangji, 525.

${ }^{80}$ Ye Dehui, “Postface” in Ye, Shuxiangge yilu, 149. 